\title{
Factor analysis models in enterprise costs management
}

\author{
G. Bakulina ${ }^{1}$, V. Fedoskin ${ }^{1}$, M. Pikushina ${ }^{1}$, V. Kukhar ${ }^{2}$, E. Kot $^{2}$ \\ ${ }^{1}$ Ryazan State Agrotechnological University named after P.A. Kostychev \\ ${ }^{2}$ Ural State Agrarian University \\ Russian Federation
}

Received: March 8, 2020. Revised: May 20, 2020. 2nd Revised: June 4, 2020.

Accepted: June 16, 2020. Published: June 19, 2020.

\begin{abstract}
The process of substantiation, adoption and implementation of a managerial decision requires a lot of analytical work, which is based on the use of various economic calculations. Objective and accurate results of such an analysis are always in demand when developing and justifying managerial decisions. To estimate the impact of factor indicators on the effective feature, various factor analysis techniques have been developed based on such widely used research methods as the chain substitution method and the method of absolute differences. The main advantages of these methods are simplicity, efficiency and easy interpretation of the results. However, most of them do not give an accurate assessment of the influence of factors, since they do not take into account the sequence of replacement of indicators when performing calculations, depending on the degree of their significance. To analyze diversified production the problem arises how to estimate the impact of the composition of produced heterogeneous products on effective economic indicators, such as profit and total costs. Such a situation leads to the implementation of an incorrect production diversification strategy and errors in the formation of an optimal market composition. The article discusses and substantiates ways to eliminate identified problems in the construction of factor models on the example of agricultural production.
\end{abstract}

Keywords-Factor model, costs management, effective feature, composition, comparable prices

\section{INTRODUCTION}

$\mathrm{T}$ HE process of substantiation, adoption and implementation of a managerial decision requires a lot of analytical work, which is based on the use of various economic calculations, where each specific economic indicator is presented, as a rule, in the form of a factor system or a model that imitates real controlled processes. At the same time, a manageable model is formed. The effect of the management strategy, being an effective economic indicator in the model, depends on the level and changes of its factor features. When conducting analytical work on a comprehensive study of economic processes and phenomena, quite often there is a need to estimate the degree of influence of various causes (factors) on the change in the final indicators that reflect the essence of these processes and phenomena in absolute terms. Such an estimation is carried out using the methodology of factor analysis based on models of the multiplicative type, where the effective feature is presented as a product of several factors.

The accuracy of estimates of the influence of factor indicators on the effective one depends on the correctness of their position in the factor model, which is often not observed in models of the traditional type. The most significant shortcomings in the construction of factor models were identified and demonstrated using the model of the total cost of gross agricultural production as an example.

The methodological and theoretical foundations of factor analysis are widely covered in scientific studies of Russian and foreign authors, such as Bakanov M.I., Sheremet A.D., Gilyarovskaya L.T., Bank V.R., Kovalev V.V., Savitskaya G.V., Hedderwick K., Helfert E. et al. [1] - [7].

Existing methods do not guarantee complete objectivity and accuracy of the results obtained when estimating the degree of influence of factor indicators on the effective feature, since not all methods fully comply with established rules and principles of factor analysis.

This is due to the fact that all factor indicators in the model should be arranged in a certain order: first quantitative ones, ranked by importance, and only then qualitative ones, also ranked by significance.

The division of factor indicators into quantitative and qualitative is not always objective, since the same economic indicator in different factor models can be both quantitative and qualitative. It also leads to some distortion of the results of factor analysis. When conducting a factor analysis of the total cost of production, two approaches are used. The first one involves the division of costs into fixed and variable. The second one does not take into account the degree of dependence of costs on production volumes.

The first approach involves the use of the following model: 


$$
\mathrm{Z}^{\mathrm{TOTAL}}=\sum\left(\mathrm{P}^{\mathrm{TOTAL}} \cdot \mathrm{Sp}^{\mathrm{j}} \cdot \mathrm{R}^{\mathrm{Vj}}\right)+\mathrm{R}^{\mathrm{C}},
$$

where $\mathrm{Z}^{\text {TOTAL }}$ is total gross agricultural production costs; $\mathrm{P}^{\text {TOTAL }}$ is total production;

$\mathrm{Sp}^{\mathrm{j}}$ is the share of the $\mathrm{j}$-th product in total;

$\mathrm{R}^{\mathrm{V}} \mathrm{j}$ is the rate of variable costs per unit of the $\mathrm{j}$-th type of product;

$\mathrm{R}^{\mathrm{C}}$ is the absolute amount of fixed costs.

When decoding in this factor model, it is not indicated in which units (physical or value) the indicator of the total volume of production is used.

At the same time, it is impossible to summarize heterogeneous types of products (milk, grain, potatoes, etc.) in physical units.

Based on this idea, it can be unambiguously argued that, having the symbols for the total volume of production and the share of the $\mathrm{j}$-th types of products in the factor model, one will not be able to calculate the production volume of each specific type of agricultural products in physical units, and therefore one will not be able to determine the amount of variable costs for each type of product and their total amount.

Besides, it does not specify which of costs in the status of quantitative (the absolute amount of costs or the rate of variable costs per production unit) is an indicator of the first order, and which one is the second order indicator. Such ranking is one of the most important elements of the factor analysis methodology, since the sequence of replacing the base values of factor indicators with the reporting ones in the process of transition from the initial (base) factor model to the final (reporting) one depends on it. Therefore, this has a direct impact on the objectivity of the results of factor analysis. In this regard, there is a need to improve the methodological aspects of factor analysis for management decisions [8],[9].

\section{MATERIALS AND METHODS}

The above factor model of total costs for the production of gross agricultural products has a structural factor indicator, which determines the use of the chain substitution method when determining the influence of factors, that is, it is necessary to carry out the transition from the initial (basic, planned) factor model to the reporting (actual) sequential replacement of basic (planned) values of factor indicators for reporting (actual, forecasted) ones. Herewith, the factor model of total costs is presented in the following form:

$$
\mathrm{Z}^{\mathrm{TOTAL}}=\sum\left(\mathrm{P}^{\mathrm{TOTAL}} \cdot \mathrm{Sp}^{\mathrm{j}} \cdot \mathrm{R}^{\mathrm{V} j}\right)+\mathrm{R}^{\mathrm{C}}
$$

In our opinion, the arrangement of factors in this model does not correspond to the degree of their significance and leads to distortion of results of the factor analysis.

The transition from the planned (initial, base) factorial model to the actual (reporting, final) one allows to get the following values:

\begin{tabular}{|c|c|c|c|c|}
\hline Indicator & Grain & Potato & Milk & Cattle body weight gain \\
\hline $\begin{array}{l}\text { Costs per } 1 \mathrm{dt} \text { in } 2013 \text {, rubles: } \\
\text { total, } \\
\text { including: } \\
\text { noncontrollable costs } \\
\text { fixed costs }\end{array}$ & $\begin{array}{l}520.40 \\
325.25 \\
195.15 \\
\end{array}$ & $\begin{array}{l}420.40 \\
294.30 \\
126.10\end{array}$ & $\begin{array}{l}1,310.50 \\
943.60 \\
366.90 \\
\end{array}$ & $\begin{array}{c}24,200.10 \\
\\
16,980.40 \\
7,219.70 \\
\end{array}$ \\
\hline $\begin{array}{l}\text { Costs per } 1 \mathrm{dt} \text { in } 2017 \text {, rubles: } \\
\text { total, } \\
\text { including: } \\
\text { noncontrollable costs } \\
\text { fixed costs }\end{array}$ & $\begin{array}{l}656.20 \\
437.70 \\
218.50\end{array}$ & $\begin{array}{l}545.30 \\
374.10 \\
171.20\end{array}$ & $\begin{array}{c}1,840.80 \\
1,270.40 \\
570.40\end{array}$ & $\begin{array}{c}27,350.40 \\
19,650.20 \\
7,700.20\end{array}$ \\
\hline $\begin{array}{l}\text { Volume of production, } \mathrm{dt} \text { : } \\
2013 \\
2017\end{array}$ & $\begin{array}{c}80,055 \\
139,280\end{array}$ & $\begin{array}{l}13,000 \\
39,770\end{array}$ & $\begin{array}{l}29,475 \\
35,570\end{array}$ & $\begin{array}{l}1,172 \\
1,312\end{array}$ \\
\hline
\end{tabular}

$$
\begin{aligned}
& \mathrm{Z}^{\text {TOTAL }}{ }_{\mathrm{p}}=\sum\left(\mathrm{P}^{\text {TOTAL }}{ }_{\mathrm{p}} \cdot \mathrm{Sp}_{\mathrm{p}}^{\mathrm{j}} \cdot \mathrm{R}^{\mathrm{V}{ }_{\mathrm{p}}}\right)+\mathrm{R}_{\mathrm{p}}^{\mathrm{C}} \text {; } \\
& \mathrm{Z}^{\text {TOTAL }} \text { equiv. } 1=\sum\left(\mathrm{P}^{\text {TOTAL }}{ }_{\mathrm{f}} \cdot \mathrm{Sp}_{\mathrm{p}}^{\mathrm{j}} \cdot \mathrm{R}^{\mathrm{Vj}}{ }_{\mathrm{p}}\right)+\mathrm{R}_{\mathrm{p}}^{\mathrm{C}} \text {; } \\
& \mathrm{Z}^{\text {TOTAL }}{ }_{\text {equiv. } 2}=\sum\left(\mathrm{P}_{\mathrm{TOTAL}} \cdot \mathrm{Sp}_{\mathrm{f}}^{\mathrm{j}} \cdot \mathrm{R}^{\mathrm{Vj}}{ }_{\mathrm{p}}\right)+\mathrm{R}_{\mathrm{p}}^{\mathrm{C}} \text {; } \\
& \mathrm{Z}^{\text {TOTAL }}{ }_{\mathrm{f}}=\sum\left(\mathrm{P}^{\text {TOTAL }}{ }_{\mathrm{f}} \cdot \mathrm{Sp}_{\mathrm{f}}^{\mathrm{j}_{\mathrm{f}}} \cdot \mathrm{R}^{\mathrm{V} \mathrm{j}_{\mathrm{f}}}\right)+\mathrm{R}_{\mathrm{p}}^{\mathrm{C}} \text {; } \\
& Z^{\text {TOTAL }}{ }_{f}=\sum\left(P^{\text {TOTAL }_{f}} \cdot \mathrm{Sp}_{\mathrm{f}}^{\mathrm{j}_{\mathrm{f}}} \cdot \mathrm{R}_{\mathrm{f}}^{\mathrm{V}}{ }_{\mathrm{f}}\right)+\mathrm{R}_{\mathrm{f}}^{\mathrm{C}} \text {. }
\end{aligned}
$$

Table 1. The volume of production and costs per unit of output

In our opinion, the location of factor indicators in the factor model should be as follows:

$$
\mathrm{Z}^{\text {TOTAL }}{ }_{\mathrm{p}}=\mathrm{R}_{\mathrm{p}}^{\mathrm{C}}+\sum\left(\mathrm{P}_{\mathrm{TOTAL}} \cdot \mathrm{Sp}_{\mathrm{p}}^{\mathrm{j}} \cdot \mathrm{R}_{\mathrm{p}}^{\mathrm{V}}{ }_{\mathrm{p}}\right)
$$

where: $\mathrm{R}^{\mathrm{C}}$ is fixed costs that are independent of production volumes. In any case, fixed costs are first and foremost incurred. Therefore, this factor indicator $\left(\mathrm{R}_{\mathrm{C}}^{\mathrm{C}}\right)$ in terms of significance should be a first-order indicator in the ranked row and, therefore, its base (planned) value should be first replaced by a reporting (actual) value to obtain the first conditional value ( $\mathrm{Z}^{\text {TOTAL }}$ cond. 1$)$ :

$$
\mathrm{Z}^{\text {TOTAL }} \text { equiv. } 1=\mathrm{R}_{\mathrm{f}}^{\mathrm{C}}+\sum\left(\mathrm{P}_{\mathrm{p}}^{\mathrm{TOTAL}} \cdot \mathrm{Sp}_{\mathrm{p}}^{\mathrm{j}} \cdot \mathrm{R}_{\mathrm{p}}^{\mathrm{V}}{ }_{\mathrm{p}}\right),(4)
$$

In the production of fixed costs (depreciation, rent, salaries of the administrative and managerial apparatus, etc.) it is impossible to obtain products, because for production it is necessary to spend raw materials, materials, labor, that is, variable costs are required. Consequently, the basic (planned) value of the factor indicator of specific variable costs $\left(R^{\mathrm{V}}\right)$ will change second according to the degree of significance to calculate the second conditional value: 


$$
\mathrm{Z}^{\text {TOTAL }} \text { equiv. } 2=\mathrm{R}_{\mathrm{f}}^{\mathrm{C}}+\sum\left(\mathrm{R}^{\mathrm{Vj}}{ }_{\mathrm{f}} \cdot \mathrm{P}^{\mathrm{TOTAL}}{ }_{\mathrm{p}} \cdot \mathrm{Sp}_{\mathrm{p}}^{\mathrm{j}}\right),(5)
$$

It is known that a certain volume of production will be obtained only after the production of costs. Then, as a factor indicator, the total production volume $\left(\mathrm{P}^{\mathrm{TOTAL}}\right)$ in the factor model will be the third in terms of significance, and therefore its value will be replaced third:

$$
\mathrm{Z}^{\text {TOTAL }} \text { equiv. } 3=\mathrm{R}_{\mathrm{f}}^{\mathrm{C}}+\sum\left(\mathrm{R}^{\mathrm{Vj}}{ }_{\mathrm{f}} \cdot \mathrm{P}^{\mathrm{TOTAL}_{\mathrm{f}}} \cdot \mathrm{Sp}_{\mathrm{p}}^{\mathrm{j}}\right),
$$

A change in the total gross agricultural output will be a consequence of an increase or decrease in the production volume of each individual type of product, which will cause a change in the share of these species in the total.

Therefore, the share of each particular type of product in the total volume $\left(\mathrm{Sp}^{\mathrm{j}}\right)$ will be the fourth most significant one in the ranked row and the calculation of actual total costs $\left(\mathrm{Z}^{\mathrm{TOTAL}}{ }_{\mathrm{f}}\right)$ will have the following form:

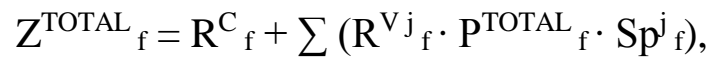

Given the above, the location of factor indicators in the transition from the original model to the final one will be as follows:

$$
\begin{aligned}
& \mathrm{Z}^{\text {TOTAL }}{ }_{\mathrm{p}}=\mathrm{R}_{\mathrm{p}}^{\mathrm{C}}+\sum\left(\mathrm{R}^{\mathrm{Vj}}{ }_{\mathrm{p}} \cdot \mathrm{P}^{\mathrm{TOTAL}}{ }_{\mathrm{p}} \cdot \mathrm{Sp}_{\mathrm{p}}^{\mathrm{j}}\right) \text {, } \\
& \mathrm{Z}^{\text {TOTAL }} \text { equiv. } 1=\mathrm{R}_{\mathrm{f}}^{\mathrm{C}}+\sum\left(\mathrm{R}^{\mathrm{Vj}} \cdot \mathrm{P}_{\mathrm{p}}^{\mathrm{TOTAL}_{\mathrm{f}}} \cdot \mathrm{P}^{\mathrm{TOTAL}}{ }_{\mathrm{p}} \cdot \mathrm{Sp}_{\mathrm{p}}^{\mathrm{j}}\right) \text {, } \\
& \mathrm{Z}^{\text {TOTAL }} \text { equiv. } 2=\mathrm{R}_{\mathrm{f}}^{\mathrm{C}}+\sum\left(\mathrm{R}^{\mathrm{Vj}}{ }_{\mathrm{f}} \cdot \mathrm{P}^{\text {TOTAL }}{ }_{\mathrm{p}} \cdot \mathrm{Sp}_{\mathrm{p}}^{\mathrm{j}}\right) \text {, } \\
& \mathrm{Z}^{\text {TOTAL }} \text { equiv. } 3=\mathrm{R}_{\mathrm{f}}^{\mathrm{C}}+\sum\left(\mathrm{R}^{\mathrm{Vj}}{ }_{\mathrm{f}} \cdot \mathrm{P}^{\mathrm{TOTAL}_{\mathrm{f}}} \cdot \mathrm{Sp}_{\mathrm{p}}^{\mathrm{j}}\right) \text {, } \\
& Z^{\text {TOTAL }_{f}}=R^{\mathrm{C}}{ }_{\mathrm{f}}+\sum\left(\mathrm{R}_{\mathrm{f}}^{\mathrm{Vj}} \cdot \mathrm{P}_{\mathrm{TOTAL}} \cdot \mathrm{Sp}_{\mathrm{f}}{ }_{\mathrm{f}}\right) \text {. }
\end{aligned}
$$

When using these factor models, there is a need to determine the total gross agricultural output.

However, it is impossible to summarize heterogeneous types of crop and livestock production in natural units (centners, tons, etc.). In this regard, it is not possible to determine the share of each type of product in natural units in the total volume. Therefore, it is impossible to determine the conditional 3rd value of total costs [10] - [12].

To determine the planned and actual composition of the manufactured products, heterogeneous species should be brought to a single measurer, for example, expressed in comparable prices. Then it will be possible to determine the total volume of agricultural production in value terms and calculate the share of each type of product in the total volume.

Here are the stages of calculating the notional volume of each type of manufactured products in actual measurement:

1. The cost (in comparable prices) of the total volume of production in the reporting year (actual volume) is alternately multiplied by the share of each type of product in the base year (planned share) and the notional value is determined (with the actual volume and planned composition).

2. The notional value of each type of product is divided by the corresponding comparable price and its notional volume is calculated.

3. To determine the total amount of variable costs, the equivalent production of each type of product is multiplied by the corresponding share of variable costs and the results are summarized.

To confirm the validity of such calculations, one can carry out a comparative analysis of the calculation of the conditional gross production for a group of homogeneous products (crops)using natural indicators and comparable prices. For

\begin{tabular}{|c|c|c|c|c|}
\hline & Spring wheat & Winter rye & Oat & Total \\
\hline 1. Comparable price $\left(\mathrm{CP}^{\mathrm{j}}\right)$, rub. & 10.948 & 10.190 & 10.694 & 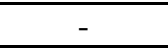 \\
\hline 2. 2013: & & & & \\
\hline 2a) the total production of the $\mathrm{j}$-th type of product $\left(\mathrm{P}_{13}\right)$, dt & 45,010 & 24,970 & 30,020 & 100,000 \\
\hline $2 \mathrm{~b})$ share by the volume of the $\mathrm{j}$-th type of product, $\left(\mathrm{Sp}^{\mathrm{Pj}}{ }_{13}\right)$ & 0.450100 & 0.249700 & 0.300200 & 1.000000 \\
\hline $\begin{array}{l}2 \mathrm{c}) \text { the cost of the volume of the } \mathrm{j} \text {-th type of product: }\left(\mathrm{CP}^{\mathrm{j}}{ }_{13}=\right. \\
\left.\mathrm{Pi}_{13} \cdot \mathrm{CP}^{\mathrm{j}}\right) \text {, rub. }\end{array}$ & 492,769 & 254,444 & 321,034 & $1,068,247$ \\
\hline 2d) share by the cost of the j-th type of product, $\left(\mathrm{Sp}^{\mathrm{Cj}}{ }_{13}\right)$ & 0.4612875 & 0.2381884 & 0.3005241 & 1.0 \\
\hline $\begin{array}{l}\text { 3. 2017: } \\
\text { 3a) the total production of the } \mathrm{j} \text {-th type of product }\left(\mathrm{P}^{\mathrm{j}}{ }_{17}\right), \mathrm{dt}\end{array}$ & 55,040 & 29,910 & 35,050 & 120,000 \\
\hline 3b) share by the volume of the $\mathrm{j}$-th type of product, $\left(\mathrm{Sp}^{\mathrm{Pj}}{ }_{17}\right)$ & 0.458667 & 0.249250 & 0.292083 & 1.000000 \\
\hline $\begin{array}{l}3 c) \text { the cost of the volume of the } \mathrm{j} \text {-th type of product }\left(\mathrm{CP}^{\mathrm{j}}{ }_{17}=\right. \\
\left.\mathrm{Pj}_{17} \cdot \mathrm{CPj}\right)\end{array}$ & 602578 & 304783 & 374825 & 1282186 \\
\hline $3 \mathrm{~d})$ share by the cost of the $\mathrm{j}$-th type of product, $\left(\mathrm{Sp}^{\mathrm{Cj}}{ }_{17}\right)$ & 0.4699614 & 0.2377058 & 0.2923328 & 1.0 \\
\hline $\begin{array}{l}\text { 4. } 2017 \text { production volume in terms of } 2013 \text { composition: } \\
\text { 4a) the cost of the equivalent production of the } \mathrm{j} \text {-th type of } \\
\text { product, rub.: } \\
\left(\mathrm{CP}^{\mathrm{j}}{ }_{\text {equiv. }}=\mathrm{CP}^{\mathrm{j}}{ }_{17} \cdot \mathrm{Sp}^{\mathrm{Cj}}{ }_{13}\right)\end{array}$ & $591,456.37$ & $305,401.83$ & $385,327.80$ & $1,275,816$ \\
\hline $\begin{array}{l}4 \mathrm{~b}) \text { equivalent production calculated at cost, } \mathrm{dt}:\left(\mathrm{P}^{\mathrm{j}} \text { equiv. }=\right. \\
\left.\mathrm{CP}^{\mathrm{j}} \text { cond. } \mathrm{CP}^{\mathrm{j}}\right)\end{array}$ & $54,024.15$ & $29,970.74$ & $36,032.15$ & $120,027.04$ \\
\hline $\begin{array}{l}\text { 4c) equivalent production calculated by natural weight, dt: } \\
\left(\mathrm{P}_{\text {equiv. }}=\mathrm{P}^{\mathrm{TOTAL}}{ }_{17} \cdot \mathrm{Sp}^{\mathrm{Pj}}{ }_{13}\right)\end{array}$ & 54,012 & 29,964 & 36,024 & 120,000 \\
\hline
\end{tabular}
homogeneous products, it is possible to use natural indicators when determining the share, since such products can be summed in physical terms. Compare the results of calculations of structural characteristics and conditional indicators in physical terms and according to the proposed methodology. [13]- [18]. The calculation results are presented in Table 2.

Table 2. The volume of production and total costs of bulk yield 
5. The absolute amount of fixed costs in $2017\left(\mathrm{R}^{\mathrm{c}}{ }_{17}\right)$, rub.

6. Variable costs for $1 \mathrm{dt}$ (rate of variable costs per unit of output), rub.

Total costs (fixed + variable) for the equivalent production will be:

$$
\begin{gathered}
\mathrm{Z}^{\text {TOTAL }} \text { equiv. } 3=\mathrm{R}^{\mathrm{C}}+\mathrm{R}^{\mathrm{V}}=30,123,984 \text { rub. }+48,434,982 \\
\text { rub. }=78,558,966 \text { rub. }
\end{gathered}
$$

The sum of variable costs of the conditional gross yield of crops, calculated on the basis of the share of the cost in comparable prices:

$\mathrm{R}^{\mathrm{P}}=437.70 \mathrm{rub} \cdot \cdot 54,024.15 \mathrm{dt}+397.92 \mathrm{rub} \cdot \cdot 29,970.74$

$\mathrm{dt}+357.28 \mathrm{rub} \cdot \cdot 36,032.15 \mathrm{dt}=48,445,893.87 \mathrm{rub}$.

Then the total cost of the equivalent production will be:

$$
\begin{aligned}
& \mathrm{Z}^{\text {TOTAL }} \text { equiv. } 3=\mathrm{R}^{\mathrm{C}}+\mathrm{R}^{\mathrm{V}}=30,123,984 \text { rub. }+ \\
& 48,445,893.87 \text { rub. }=78,569,877.87 \text { rub. }
\end{aligned}
$$

The relative difference in the equivalent production in physical terms calculated by two methods is only $0.0225 \%$ :

$$
(120,027.04 \mathrm{dt} / 120,000 \mathrm{dt}) \cdot 100=100.0225 \%
$$

The difference in total costs for the equivalent production is also insignificant (only $0.0139 \%$ ):

$$
(78,569,877.87 \text { rub. : 78,558,966 rub.) } \cdot 100=100.0139 \%
$$

Minor discrepancies in hundredths of a percent give reason to carry out the calculation of the equivalent production of heterogeneous types of products using comparable prices.

One can carry out similar calculations for heterogeneous
437.70

397.92

products.

Following the sequence of calculations, the calculation of the equivalent production is carried out according to the formula:

$$
\mathrm{Z}^{\text {TOTAL }} \text { equiv. } 3=\mathrm{R}_{\mathrm{f}}^{\mathrm{C}}+\sum\left(\mathrm{P}_{\mathrm{TOTAL}} \cdot \mathrm{Sp}_{\mathrm{p}}^{\mathrm{j}} \cdot \mathrm{R}_{\mathrm{fj}}^{\mathrm{Pj}}\right)
$$

The algorithm for calculating the equivalent production of a particular product has the following form:

$$
\mathrm{P}_{\text {equiv. }}^{\mathrm{j}}=\left[\sum\left(\mathrm{P}_{17}^{\mathrm{j}} \cdot \mathrm{CP}^{\mathrm{j}}\right)\right] \cdot \mathrm{Sp}^{\mathrm{Cj}}{ }_{13} / \mathrm{CP}^{\mathrm{j}},
$$

where: $\mathrm{P}^{\mathrm{j}}$ equiv. is the equivalent production of the $\mathrm{j}$-th type of product (for the overall production of 2017 with the composition of 2013), dt;

$\mathrm{CP}^{\mathrm{j}}$ is the comparable price of the $\mathrm{j}$-th type of product, rub.;

$\mathrm{Sp}^{\mathrm{Cj}}$ is the share of the $\mathrm{j}$-th type of product in the cost of gross output, coefficient;

$\left(\mathrm{P}^{\mathrm{j}}{ }_{17} \cdot \mathrm{CP}^{\mathrm{j}}\right)$ is the cost of the $\mathrm{j}$-th product in comparable prices in 2017, rub.;

$\left[\sum\left(\mathrm{P}_{17} \cdot \mathrm{CP}^{\mathrm{j}}\right)\right]$ is the cost (in comparable prices) of the overall crop and livestock production in 2017, rub.;

$\left[\sum\left(\mathrm{P}_{17}{ }_{17} \cdot \mathrm{CP}^{\mathrm{j}}\right)\right] \cdot \mathrm{Sp}^{\mathrm{Cj}}{ }_{13}$ is the cost of the $\mathrm{j}$-th type of agricultural products with the overall production of 2017 and

\begin{tabular}{|c|c|c|c|c|c|}
\hline Indicator & Grain & Potato & Milk & $\begin{array}{l}\text { Cattle body } \\
\text { weight gain }\end{array}$ & Total \\
\hline 1. Comparable price $\left(\mathrm{CP}^{\mathrm{j}}\right)$, rub. & 10.948 & 31.516 & 29.633 & 113.828 & - \\
\hline $\begin{array}{l}\text { 2. 2013: } \\
\text { 2a) the total production of the } \mathrm{j} \text {-th type of } \\
\text { product }\left(\mathrm{P}_{13}\right), \mathrm{dt}\end{array}$ & 80,055 & 13,000 & 29,475 & 1,172 & - \\
\hline $\begin{array}{l}\text { 2b) the cost of the volume of the } \mathrm{j} \text {-th type of } \\
\text { product: }\left(\mathrm{CP}^{\mathrm{j}}{ }_{13}=\mathrm{P}_{13}^{\mathrm{j}} \cdot \mathrm{CP}^{\mathrm{j}}\right) \text {, rub. } \\
2 \mathrm{c}) \text { share by the cost of the } \mathrm{j} \text {-th type of product, } \\
\left(\mathrm{Sp}^{\mathrm{C}} \mathrm{j}_{13}\right)\end{array}$ & $\begin{array}{c}876,442 \\
0.382\end{array}$ & $\begin{array}{c}409,708 \\
0.179 \\
\end{array}$ & $\begin{array}{c}873,433 \\
0.381\end{array}$ & $\begin{array}{c}133,406 \\
0.058\end{array}$ & $\begin{array}{c}2,292,989 \\
1.0 \\
\end{array}$ \\
\hline $\begin{array}{l}\text { 3. 2017: } \\
\text { 3a) the total production of the } \mathrm{j} \text {-th type of } \\
\text { product }\left(\mathrm{Pj}_{17}\right), \mathrm{dt} \\
\text { 3b) the cost of the volume of the } \mathrm{j} \text {-th type of } \\
\text { product }\left(\mathrm{CP}^{\mathrm{j}}{ }_{17}=\mathrm{Pj}_{17} \cdot \mathrm{CP}^{\mathrm{j}}\right) \text {, rub. } \\
3 \mathrm{c}) \text { share by the cost of the } \mathrm{j} \text {-th type of product, } \\
\left(\mathrm{Sp}^{\mathrm{C}} \mathrm{j}_{17}\right)\end{array}$ & $\begin{array}{c}1,524,837 \\
0.383\end{array}$ & $\begin{array}{c}39,770 \\
1,253,391 \\
0.315\end{array}$ & $\begin{array}{c}35,570 \\
1,054,046 \\
0.265\end{array}$ & $\begin{array}{c}1,312 \\
149,342 \\
0.037\end{array}$ & $\begin{array}{c}3,981,616 \\
1.0\end{array}$ \\
\hline 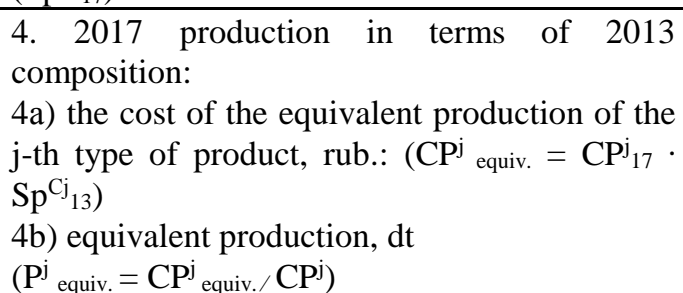 & $\begin{array}{l}1,520,977 \\
138,927\end{array}$ & $\begin{array}{l}712,709 \\
22,614\end{array}$ & $\begin{array}{c}1,516,996 \\
51,193\end{array}$ & $\begin{array}{c}230,934 \\
2,029\end{array}$ & $3,981,616$ \\
\hline
\end{tabular}
the composition (share of each specific type of product in the overall production) of 2013, rub.;

$\left[\sum\left(\mathrm{P}_{17} \cdot \mathrm{CP}^{\mathrm{j}}\right)\right] \cdot \mathrm{Sp}^{\mathrm{Cj}}{ }_{13} / \mathrm{CP}^{\mathrm{j}}$ is equivalent production of the $\mathrm{j}-$ th type of agricultural products, $\mathrm{dt}$.

Let's carry out the necessary calculations in accordance with the algorithm, taking into account the data presented in Tables.

Table 3. The volume of output and the cost of certain types of products 
Next, the influence of factors on the basis of the recommended factor model will be calculated.

1. 2013 costs are calculated using the following factor model:

$$
\mathrm{Z}^{\mathrm{TOTAL}}{ }_{13}=\left\{\mathrm{R}_{13}^{\mathrm{C}}+\sum\left[\mathrm{R}^{\mathrm{Vj}_{13}} \cdot\left(\mathrm{P}^{\mathrm{TOTAL}_{13}} \cdot \mathrm{Sp}_{13}^{\mathrm{j}}\right)\right]\right\},
$$

It should be noted that in this model, part of the expression

in parentheses $\left(\mathrm{P}^{\mathrm{TOTAL}}{ }_{13} \cdot \mathrm{Sp}^{\mathrm{j}}{ }_{13}\right)$ is equivalent and corresponds to the output (in physical terms) of the $\mathrm{j}$-th type of agricultural production in 2013.

Therefore, to calculate the total costs, this factor model can be presented in a more simplified form:

$$
\mathrm{Z}^{\mathrm{TOTAL}}{ }_{13}=\left[\mathrm{R}^{\mathrm{C}}{ }_{13}+\sum\left(\mathrm{R}^{\mathrm{Pj}}{ }_{13} \cdot \mathrm{P}_{13}\right)\right] \text {, }
$$

The output of each type of crop production is shown in Tables 1 and 2 :

$$
\mathrm{Z}^{\text {TOTAL }}{ }_{13}=36,537,899.15+(325.25 \mathrm{rub} \cdot \cdot 80,055 \mathrm{dt})+
$$

$(294.30 \mathrm{rub} \cdot \cdot 13,000 \mathrm{dt})+(943.60 \mathrm{rub} \cdot \cdot 29,475 \mathrm{dt})+$

$(16,980.40 \mathrm{rub} \cdot \cdot 1,172 \mathrm{dt})=36,537,899,15+26,037,888.75+$ $3,825,900.00+27,812,610.00+19,901,028.80=$

$36,537,899.15+77,577,427.55=114,115,326.70$ (rub.) $=$ $114,115.3$ (thousand rub.)

2. The first equivalent value of costs is:

$$
\mathrm{Z}^{\text {TOTAL }} \text { equiv. } 1=\left\{\mathrm{R}_{17}^{\mathrm{C}_{17}}+\sum\left[\mathrm{R}^{\mathrm{Pj}_{13}} \cdot\left(\mathrm{P}^{\mathrm{TOTAL}}{ }_{13} \cdot \mathrm{Sp}^{\mathrm{j}}{ }_{13}\right)\right]\right\},
$$

In a simplified form, the factor model will look as follows:

$$
\mathrm{Z}^{\text {TOTAL }} \text { equiv. } 1=\left[\mathrm{R}_{17}^{\mathrm{C}}+\sum\left(\mathrm{R}^{\mathrm{Pj}_{13}} \cdot \mathrm{Pj}_{13}\right)\right] \text {, }
$$

The value of fixed costs in this model is replaced from the base (planned) one to reporting (actual) one. The value of all other factor indicators does not change and remains at the basic (planned) level:

$$
\begin{gathered}
\mathrm{Z}^{\text {TOTAL }} \text { equiv. } 1=67,633,094.40+(325.25 \mathrm{rub} \cdot \cdot 80,055 \mathrm{dt})+ \\
(294.30 \mathrm{rub} \cdot \cdot 13,000 \mathrm{dt})+(943.60 \mathrm{rub} \cdot \cdot 29,475 \mathrm{dt})+ \\
(16,980.40 \mathrm{rub} \cdot \cdot 1,172 \mathrm{dt})=67,633,094.40+26,037,888.75+ \\
3,825,900.00+27,812,610.00+19,901,028.80= \\
67,633,094.40+77,577,427.55=145,210,521.95 \text { (rub. })= \\
145,210.5 \text { (thousand rub.) }
\end{gathered}
$$

3. The second equivalent value of costs is:
ZTOTAL equiv. $2=\left\{\mathrm{RC} 17+\sum\left[\mathrm{R}^{\mathrm{Pj}_{17}} \cdot\left(\mathrm{P}^{\mathrm{TOTAL}}{ }_{13} \cdot \mathrm{Sp}_{13}^{\mathrm{j}}\right)\right]\right\}$, (14)

or in a simplified form:

$$
\mathrm{Z}^{\text {TOTAL }} \text { equiv. } 2=\left[\mathrm{R}^{\mathrm{C}}{ }_{17}+\sum\left(\mathrm{R}^{\mathrm{Pj}_{17}} \cdot \mathrm{P}_{13}{ }_{13}\right)\right] .
$$

When calculating this equivalent value of total costs in the factor model, the basis (planned) values were replaced by reporting (actual) ones for such indicators as fixed and variable costs. The values of the gross output and its composition remain at the basic (planned) level.

$$
\begin{gathered}
\mathrm{Z}^{\text {TOTAL }} \text { equiv. }=67,633,094.40+(437.70 \mathrm{rub} \cdot \cdot 80,055 \mathrm{dt})+ \\
(374.10 \mathrm{rub} \cdot \cdot 13,000 \mathrm{dt})+ \\
(1,270.40 \mathrm{rub} \cdot \cdot 29,475 \mathrm{dt})+(19,650.20 \mathrm{rub} \cdot \cdot 1,172 \mathrm{dt})= \\
67,633,094.40+35,040,073.50+4,863,300.00+ \\
37,445,040.00+23,030,034.40=67,633,094.40+ \\
100,378,447.90=168,011,542.30 \text { (rub. })=168,011.5 \\
\text { (thousand rub.) }
\end{gathered}
$$

\begin{tabular}{|c|c|c|c|c|c|}
\hline \multirow[b]{2}{*}{ Indicator } & \multirow{2}{*}{$\begin{array}{l}\text { Total costs, } \\
\text { thousand } \\
\text { rub. }\end{array}$} & \multicolumn{4}{|c|}{ Cost factors } \\
\hline & & $\begin{array}{l}\text { Fixed costs } \\
\left(\mathrm{R}^{\mathrm{C}}\right)\end{array}$ & $\begin{array}{l}\text { Variable costs } \\
\qquad\left(\mathrm{R}^{\mathrm{PJ}}\right)\end{array}$ & $\begin{array}{l}\text { Volume of } \\
\text { output }\left(\mathrm{P}^{\mathrm{J}}\right)\end{array}$ & $\begin{array}{l}\text { Composition of } \\
\text { output }\left(\mathrm{Sp}^{\mathrm{J}}\right)\end{array}$ \\
\hline $\begin{array}{l}\text { 1. Costs of } 2013\left(\mathrm{Z}^{\mathrm{TOTAL}_{13}}\right): \\
\left\{\mathrm{R}_{13}+\sum\left[\mathrm{R}^{\mathrm{P}{ }_{13}} \cdot\left(\mathrm{P}^{\mathrm{TOTAL}_{13}} \cdot \mathrm{Sp}_{13}{ }_{13}\right)\right]\right\}\end{array}$ & $114,115.3$ & $\mathrm{R}_{13}^{\mathrm{C}_{13}}$ & $\mathrm{R}^{\mathrm{Pj}_{3}}$ & $\mathrm{P}_{13}$ & $\mathrm{Sp}^{\mathrm{j}}{ }_{13}$ \\
\hline $\begin{array}{l}\text { 2. Costs equiv. } 1\left(\mathrm{Z}^{\mathrm{TOTAL}}{ }_{\text {equiv. } 1}\right) \text { : fixed cost } \\
2017 \text { and variable costs, total output and } \\
\text { composition of } 2013 \text { : } \\
\left\{\mathrm{R}^{\mathrm{C}}{ }_{17}+\sum\left[\mathrm{R}^{\mathrm{Pj}}{ }_{13} \cdot\left(\mathrm{P}^{\mathrm{TOTAL}}{ }_{13} \cdot \mathrm{Sp}_{13}\right)\right]\right\}\end{array}$ & $145,210.5$ & $\mathrm{R}_{17}^{\mathrm{C}}$ & $\mathrm{R}^{\mathrm{Pj}_{13}}$ & $\mathrm{P}_{13}$ & $\mathrm{Sp}^{\mathrm{j}}{ }_{13}$ \\
\hline 3. Costs equiv. 2 ( $\mathrm{Z}^{\mathrm{TOTAL}}$ equiv. 2$)$ : fixed and & & & & & \\
\hline
\end{tabular}

4. The third equivalent value of costs is: $\mathrm{Z}^{\text {TOTAL }}$ equiv. $3=$ $\left\{\mathrm{R}^{\mathrm{C}}{ }_{17}+\sum\left[\mathrm{R}^{\mathrm{Pj}}{ }_{17} \cdot\left(\mathrm{P}^{\mathrm{TOTAL}}{ }_{17} \cdot \mathrm{Sp}^{\mathrm{j}}{ }_{13}\right)\right]\right\}$.

Expression $\left(\mathrm{P}^{\mathrm{TOTAL}}{ }_{17} \cdot \mathrm{Sp}^{\mathrm{j}}{ }_{13}\right)$ in this factor model determines the equivalent production of each specific type of crop and livestock.

The equivalent production of each product has already been calculated (Table 4, line 4b).

Therefore, the factor model of total equivalent costs 3 can be expressed in a more simplified form: $\mathrm{Z}^{\mathrm{TOTAL}}$ equiv. $3=\left[\mathrm{R}^{\mathrm{C}}{ }_{17}+\sum\right.$ $\left.\left(\mathrm{R}^{\mathrm{Pj}}{ }_{17} \cdot \mathrm{Pj}_{\text {equiv. }}\right)\right]$.

$$
\begin{gathered}
\mathrm{Z}^{\text {TOTAL }} \text { equiv. }=67,633,094.40+(437.70 \mathrm{rub} \cdot \cdot 138,927 \mathrm{dt})+ \\
(374.10 \mathrm{rub} \cdot \cdot 22,614 \mathrm{dt})+ \\
(1,270.40 \mathrm{rub} \cdot \cdot 51,193 \mathrm{dt})+(19,650.20 \mathrm{rub} \cdot \cdot 2,029 \mathrm{dt})= \\
67,633,094.40+60,808,347.90+8,159,897.40+ \\
65,035,587.20+39,870,255.80=67,633,094.40+ \\
173,874,088.30=241,507,182.70 \text { (rub. })=241,507.2
\end{gathered}
$$

(thousand rub.)

5. 2017 costs (reported, actual) are calculated using the following factor model:

$$
\mathrm{Z}^{\mathrm{TOTAL}}{ }_{17}=\left\{\mathrm{R}^{\mathrm{C}}{ }_{17}+\sum\left[\mathrm{R}^{\mathrm{Vj}_{17}} \cdot\left(\mathrm{P}^{\mathrm{TOTAL}}{ }_{17} \cdot \mathrm{Sp}^{\mathrm{j}}{ }_{17}\right)\right]\right\}
$$

The results of the calculations are presented in Table 4.

Table 4. Factor analysis of the total cost of production with the division into fixed and variable costs 


\begin{tabular}{|c|c|c|c|c|c|}
\hline $\begin{array}{l}\text { variable costs of } 2017 \text { and total output and } \\
\text { composition of } 2013 \text { : } \\
\left\{\mathrm{R}^{\mathrm{C}}{ }_{17}+\sum\left[\mathrm{R}^{\mathrm{Pj}}{ }_{17} \cdot\left(\mathrm{P}^{\mathrm{TOTAL}}{ }_{13} \cdot \mathrm{Sp}^{\mathrm{j}}{ }_{13}\right)\right]\right\}\end{array}$ & $168,011.5$ & $\mathrm{R}_{17}^{\mathrm{C}_{17}}$ & $\mathrm{R}^{\mathrm{Pj}_{17}}$ & $\mathrm{Pj}_{13}$ & $\mathrm{Sp}_{13}^{\mathrm{j}}$ \\
\hline $\begin{array}{l}\text { 4. Costs equiv. } 3\left(\mathrm{Z}^{\mathrm{TOTAL}} \text { equiv. } 3\right) \text { : fixed and } \\
\text { variable costs, total output of } 2017 \text { and } \\
\text { composition of } 2013 \text { : } \\
\left\{\mathrm{R}^{\mathrm{C}}{ }_{17}+\sum\left[\mathrm{R}^{\mathrm{Pj}}{ }_{17} \cdot\left(\mathrm{P}^{\mathrm{TOTAL}}{ }_{17} \cdot \mathrm{Sp}^{\mathrm{j}}{ }_{13}\right)\right]\right\}\end{array}$ & $241,507.2$ & $\mathrm{R}^{\mathrm{C}_{17}}$ & $\mathrm{R}^{\mathrm{Pj}}{ }_{17}$ & $\mathrm{Pj}_{17}$ & $S \mathrm{p}_{13}^{\mathrm{j}}$ \\
\hline $\begin{array}{l}\text { 5. Costs of } 2017\left(\mathrm{Z}^{\mathrm{TOTAL}_{17}}\right): \\
\left\{\mathrm{R}_{17}^{\mathrm{C}}+\sum\left[\mathrm{R}^{\mathrm{Pj}_{17}} \cdot\left(\mathrm{P}^{\mathrm{TOTAL}_{17}} \cdot \mathrm{Sp}_{17}{ }_{17}\right)\right]\right\}\end{array}$ & $214,443.1$ & $\mathrm{R}^{\mathrm{C}}{ }_{17}$ & $\mathrm{R}^{\mathrm{Pj}}{ }_{17}$ & $\mathrm{Pj}_{17}$ & $\mathrm{Sp}_{17}^{\mathrm{j}}$ \\
\hline
\end{tabular}

The absolute amount of fixed costs in 2013 is as follows:

$$
\begin{aligned}
\mathrm{R}^{\mathrm{C}_{13}=} & 195.15 \cdot 80,055+126.10 \cdot 13,000+366.90 \cdot 29,475 \\
& +7,219.70 \cdot 1,172=36,537,899.15 \text { (rub.) }
\end{aligned}
$$

The absolute amount of fixed costs in 2017 is as follows:

$$
\begin{gathered}
\mathrm{R}^{\mathrm{C}_{17}=} 218.50 \cdot 139,280+171.20 \cdot 39,770+570.40 \cdot 35,570 \\
+7,700.20 \cdot 1,312=67,633,094.40 \text { (rub.) }
\end{gathered}
$$

It should be noted that in this model, as has been repeatedly mentioned above, part of the expression in parentheses $\left(\mathrm{P}^{\mathrm{TOTAL}_{13}} \cdot \mathrm{Sp}_{13}^{\mathrm{j}}\right)$ is conventional and corresponds to the volume (in physical terms) of the $\mathrm{j}$-th type of agricultural production in 2017.

Using the data in Table 4, the total deviation of the actual (reporting) costs from the planned (base) ones is determined).

$$
\begin{gathered}
\Delta \mathrm{Z}^{\mathrm{TOTAL}}=\left\{\mathrm{R}^{\mathrm{C}}{ }_{17}+\sum\left[\mathrm{R}^{\mathrm{Pj}}{ }_{17} \cdot\left(\mathrm{P}^{\mathrm{TOTAL}}{ }_{17} \cdot \mathrm{Sp}^{\mathrm{j}}{ }_{17}\right)\right]\right\}-\left\{\mathrm{R}^{\mathrm{C}}{ }_{13}+\sum\right. \\
\left.\left[\mathrm{R}^{\mathrm{Pj}}{ }_{13} \cdot\left(\mathrm{P}^{\mathrm{TOTAL}}{ }_{13} \cdot \mathrm{Sp}^{\mathrm{j}}{ }_{13}\right)\right]\right\}=214,443.1 \text { thousand rub. }- \\
114,115.3 \text { thousand rub. }=+100,327.8 \text { thousand rub. }
\end{gathered}
$$

In general, the total cost of gross agricultural production increased by $100,327.8$ thousand rubles.

As a result of changes in fixed costs, total costs increased by 31,095.2 thousand rubles:

$$
\Delta \mathrm{Z}^{\mathrm{RC}}=\mathrm{Z}^{\mathrm{TOTAL}} \text { equiv. } 1-\mathrm{Z}^{\mathrm{TOTAL}}{ }_{13}=145,210.5 \text { thousand rub. - }
$$

$114,115.3$ thousand rub. $=+31,095.2$ thousand rub.

The increase in out-of-pocket unit costs $\left(\mathrm{R}^{\mathrm{Pj}}\right)$ with a constant value of the remaining factor indicators leads to an increase in total costs by $22,801.0$ thousand rub.:

$\Delta Z^{\mathrm{RV}}=\mathrm{Z}^{\mathrm{TOTAL}}$ equiv. $2-\mathrm{Z}^{\mathrm{TOTAL}}$ equiv. $1=168,011.5$ thousand rub. $-145,210.5$ thousand rub. $=+22,801.0$ thousand rub.

The cost of gross output (in comparable prices) increased by $73.6 \%$, which indicates an increase in the production of specific types of agricultural products in physical terms. At the same time, total costs increased by $73,495.7$ thousand rubles:

$\Delta \mathrm{Z}^{\mathrm{Pj}}=\mathrm{Z}^{\mathrm{TOTAL}}$ equiv. $3-\mathrm{Z}^{\mathrm{TOTAL}}$ equiv. $2=241,507.2$ thousand rub. $-168,011.5$ thousand rub. $=+73,495.7$ thousand rub.

Changing the composition of manufactured products allowed to reduce the total costs of agricultural production by $27,064.1$ thousand rubles:

$$
\begin{gathered}
\Delta Z^{\mathrm{Sp}}=\mathrm{Z}^{\mathrm{TOTAL}}{ }_{17}-\mathrm{Z}^{\mathrm{TOTAL}} \text { equiv. } 3=214,443.1 \text { thousand rub. }- \\
241,507.2 \text { thousand rub. }=-27,064.1 \text { thousand rub. }
\end{gathered}
$$

The combined influence of factors on the effective indicator corresponds to the total deviation of costs, which indicates the correctness of all calculations:

$$
\begin{aligned}
& \Delta Z^{\mathrm{TOTAL}}=\Delta Z^{\mathrm{RC}}+\Delta Z^{\mathrm{RP}}+\Delta \mathrm{Z}^{\mathrm{Pj}}+\Delta \mathrm{Z}^{\mathrm{Sp}}=(+31,095.2)+ \\
& (+22,801.0)+(+73,495.7)+(-27,064.1)=+100,327.8
\end{aligned}
$$

(thousand rub.)

\section{RESULTS AND DISCUSSION}

The methodological and theoretical foundations of the factor analysis are extensively covered in scientific studies of

Russian and foreign authors, such as Bakanov M.I., Sheremet A.D., Gilyarovskaya L.T., Bank V.R., Kovalev V.V., Savitskaya G.V., Hedderwick K., Helfert E. et al.

The works of native and foreign authors provide methods of the factor analysis of economic indicators using various techniques and methods for assessing the degree of influence of factor indicators on the effective one [19], [20].

However, in our opinion, insufficient attention in the factor analysis of changes in some economic indicators as effective ones is paid to the objectivity of the location according to the level of significance of factor indicators.

At the same time, the degree of impact of the change in factor indicators on the effective one directly depends on the correct arrangement of factor indicators in the ranked series of the factor model.

In the process of conducting research, it was found that when calculating the conditional total costs at the level of fixed and variable costs in 2017, the total production of 2017 and the structure of 2013, a logical question of determining the total volume of gross agricultural production and its structure arose.

The difficulty is connected with the above-mentioned fact that one cannot sum in natural units such diverse types of crop and livestock products as grain, potatoes, milk, cattle growth.

And based on this situation, one can make an unambiguous conclusion that it is not possible to calculate the structure of gross agricultural output by volume.

All this, in turn, does not allow determining the conditional volume of each specific type of crop and livestock production necessary to calculate the conditional total costs.

To eliminate this obstacle, it was proposed to calculate the conditional volume of production of specific types of products using comparable prices, which was shown by the example of specific calculations.

To confirm the legitimacy of such calculations using comparable prices, the conditional gross yield was determined for a group of homogeneous crops (grain crops) in physical 
units.

The use of a group of homogeneous crops as an example is connected with the fact that various types of grain products may be summed and, thus, determine the total volume of production in physical units. This allows determining the share of each type of grain production in the total volume, that is, calculating the structure of production.

Such calculations can be carried out for the base and reporting years. And this allows to determine the conditional gross yield without any problems and additional calculations, and then to calculate the conditional costs with the reporting volume of production and the basic structure.

Exactly the same calculations can be made using comparable prices, as it has been done above on the example of specific crops and livestock products.

In a comparative version, according to two approaches to determining the conditional gross yield and calculating the total conditional costs for the entire volume of grain production, all calculations are presented above.

The proposed ranking according to the degree of importance of factor indicators complies with the principles and rules of factor analysis.

A comparative assessment of the results of the factor analysis according to the generally accepted and proposed methods revealed rather significant differences in the absolute value of the influence of factor indicators on the effective one.

Table 5. The results of the factor analysis of the total cost of gross agricultural production according to the generally accepted and proposed methods

\begin{tabular}{|l|c|c|c|}
\hline \multicolumn{1}{|c|}{$\begin{array}{c}\text { Factor } \\
\text { indicators }\end{array}$} & $\begin{array}{r}\text { The value of the influence } \\
\text { of factors on the effective } \\
\text { indicator }\end{array}$ & $\begin{array}{c}\text { Results } \\
\text { deviation } \\
(+,-)\end{array}$ \\
\cline { 2 - 3 } & $\begin{array}{c}\text { Generally } \\
\text { accepted } \\
\text { methodology }\end{array}$ & $\begin{array}{c}\text { Proposed } \\
\text { methodolo } \\
\text { gy }\end{array}$ & \\
\hline $\begin{array}{l}\text { Absolute } \\
\text { amount of fixed } \\
\text { costs } \mathrm{R}^{\mathrm{C}}\end{array}$ & $+31,095.2$ & $+31,095.2$ & \\
\hline $\begin{array}{l}\text { Variable costs } \\
\text { per unit of } \\
\text { output (variable } \\
\text { cost rate) } \mathrm{R}^{\mathrm{Pj}}\end{array}$ & $+33,962.7$ & $+22,801.0$ & $-11,161.7$ \\
\hline $\begin{array}{l}\text { Output of } \\
\text { products } \mathrm{P}\end{array}$ & $+57,022.9$ & $+73,495.7$ & $+16,472.8$ \\
\hline $\begin{array}{l}\text { The of } \\
\text { composition } \\
\text { (share) } \\
\text { manufactured } \\
\text { products Sp }\end{array}$ & $-21,7530$ & $-27,064.1$ & $-5,311.1$ \\
\hline Total & $+100,327.8$ & $+100,327.8$ & \\
\hline
\end{tabular}

In our opinion, the most objective and accurate results can be obtained by the proposed method, since it complies with all the rules and principles of the factor analysis.

\section{CONCLUSION}

Studies of the generally accepted methodology for the factor analysis of the total costs of the gross agricultural production have established that they have some shortcomings that lead to false conclusions and unreasonable management decisions. The main disadvantages of traditional factor models are as follows:

- biased arrangement of factors by significance;

- the share of specific types of heterogeneous products is not taken into account due to the impossibility of calculating this indicator by traditional methods of analysis.

In this regard, we proposed and justified the ranking of importance of factor indicators in the model of total costs for the production of gross output.

As a result, it was found that factor indicators should be located in the following sequence:

1) the first-order factor indicator is fixed costs;

2) the second-order factor indicator is variable costs per production unit of a particular product (rate of variable costs per production unit);

3) the third-order factor indicator is the total agricultural output, including specific types of products;

4) the composition of products is the composition of the total output.

Based on the foregoing, the factor model of cost management will have the following form:

$$
\mathrm{Z}^{\mathrm{TOTAL}}=\mathrm{R}^{\mathrm{C}}+\sum\left[\mathrm{R}^{\mathrm{Pj}} \cdot\left(\mathrm{P}^{\mathrm{TOTAL}} \cdot \mathrm{Sp}^{\mathrm{j}}\right)\right]
$$

Based on the last factor model, the location of factor indicators in the transition from the original to the final one will be as follows:

$$
\begin{aligned}
& \mathrm{Z}^{\text {TOTAL }}{ }_{\mathrm{p}}=\left\{\mathrm{R}_{\mathrm{p}}^{\mathrm{C}}+\sum\left[\mathrm{R}^{\mathrm{Vj}}{ }_{\mathrm{p}} \cdot\left(\mathrm{P}^{\mathrm{TOTAL}}{ }_{\mathrm{p}} \cdot \mathrm{Sp}_{\mathrm{p}}^{\mathrm{j}}\right)\right]\right\} ; \\
& \mathrm{Z}^{\text {TOTAL }} \text { equiv. } 1=\left\{\mathrm{R}_{\mathrm{f}}^{\mathrm{C}}+\sum\left[\mathrm{R}^{\mathrm{Vj}}{ }_{\mathrm{p}} \cdot\left(\mathrm{P}^{\text {TOTAL }}{ }_{\mathrm{p}} \cdot \mathrm{Sp}_{\mathrm{p}}^{\mathrm{j}}\right)\right]\right\} \text {; } \\
& \mathrm{Z}^{\text {TOTAL }} \text { equiv. } 2=\left\{\mathrm{R}_{\mathrm{f}}^{\mathrm{C}}+\sum\left[\mathrm{R}^{\mathrm{Vj}_{\mathrm{f}}} \cdot\left(\mathrm{P}^{\text {TOTAL }}{ }_{\mathrm{p}} \cdot \mathrm{Sp}_{\mathrm{p}}^{\mathrm{j}}\right)\right]\right\} ; \\
& \mathrm{Z}^{\text {TOTAL }} \text { equiv. } 3=\left\{\mathrm{R}_{\mathrm{f}}^{\mathrm{C}}+\sum\left[\mathrm{R}^{\mathrm{Vj}}{ }_{\mathrm{f}} \cdot\left(\mathrm{P}^{\mathrm{TOTAL}_{\mathrm{f}}} \cdot \mathrm{Sp}^{\mathrm{j}}{ }_{\mathrm{p}}\right)\right]\right\} \text {; } \\
& \mathrm{Z}^{\mathrm{TOTAL}_{\mathrm{f}}}=\left\{\mathrm{R}_{\mathrm{f}}^{\mathrm{C}}+\sum\left[\mathrm{R}^{\mathrm{Vj}_{\mathrm{f}}} \cdot\left(\mathrm{P}^{\mathrm{TOTAL}_{\mathrm{f}}} \cdot \mathrm{Sp}_{\mathrm{f}}^{\mathrm{j}}\right)\right]\right\} .
\end{aligned}
$$

Expression $\left(\mathrm{P}^{\mathrm{TOTAL}} \cdot \mathrm{Sp}^{\mathrm{j}}\right)$ in the factor model represents the equivalent production of a particular product, the calculation of which is proposed to be carried out using comparable prices.

The methodology for calculating the conditional volume of a specific crop and livestock product is as follows:

$\mathrm{P}_{\text {equiv. }}=\left[\sum\left(\mathrm{P}_{\mathrm{f}}^{\mathrm{j}} \cdot \mathrm{CP}^{\mathrm{j}}\right)\right] \cdot \mathrm{Sp}^{\mathrm{Cj}} \mathrm{p}_{\mathrm{p}}: \mathrm{CP}^{\mathrm{j}}$, where

$\mathrm{P}^{\mathrm{j}}$ equiv. is the conditional volume of the $\mathrm{j}$-th type of product: with total production in the reporting (actual) year and with the structure of the base (planned) year, dt;

$\mathrm{CP}^{\mathrm{j}}$ is comparable price of the $\mathrm{j}$-th type of product in 1994 , rub.;

$\mathrm{Sp}^{\mathrm{Cj}} \mathrm{p}$ is the share of the $\mathrm{j}$-th type of product in the cost of gross output in the base (planned) year, coefficient;

$\left(\mathrm{P}_{\mathrm{f}}^{\mathrm{f}} \cdot \mathrm{CP}^{\mathrm{j}}\right)$ is the cost of the $\mathrm{j}$-th type of product in comparable prices in the reporting (actual) year, rub.;

$\left[\sum\left(\mathrm{P}_{\mathrm{f}}^{\mathrm{j}} \cdot \mathrm{CP}^{\mathrm{j}}\right)\right]$ is the cost (in comparable prices) of the total volume of crop and livestock production in the reporting (actual) year, rub.;

$\left[\sum\left(\mathrm{P}_{\mathrm{f}}^{\mathrm{j}} \cdot \mathrm{CP}^{\mathrm{j}}\right)\right] \cdot \mathrm{Sp}^{\mathrm{Cj}}{ }_{\mathrm{p}}$ is the cost of the $\mathrm{j}$-th type of agricultural product with the total volume of production in the reporting (actual) year and the structure (share of each specific type of product in the total volume) in the base (planned) year, rub.; 
$\left[\sum\left(\mathrm{P}_{\mathrm{f}}^{\mathrm{j}} \cdot \mathrm{CP}^{\mathrm{j}}\right)\right] \cdot \mathrm{Sp}^{\mathrm{Cj}}{ }_{\mathrm{p}}: \mathrm{CP}^{\mathrm{j}}$ is the conditional production volume of the $\mathrm{j}$-th type of agricultural product, $\mathrm{dt}$.

When using these factor models, there is a need to determine the total gross agricultural output.

However, in physical terms (centners, tons, etc.), it is not possible to summarize such diverse types of crop and livestock products as grain, potatoes, vegetables, milk, cattle growth, etc. Based on this, it is not possible to determine the share of each product in the total volume both in the base year and in the reporting year.

This means that it is not possible to determine the equivalent 3rd value of total costs, since it is necessary to calculate the conditional production volume of each specific type of agricultural product by multiplying the total actual (reported) production volume $\left(\mathrm{P}^{\text {TOTAL }}{ }_{\mathrm{f}}\right)$ by the planned (base) share $\left(\mathrm{Sp}^{\mathrm{j}}\right.$ p).

Therefore, to determine the planned and actual structure (the share of each specific type of crop and livestock production in the total volume) of agricultural products produced, heterogeneous types of products should be brought to a single measure or be expressed in comparable prices.

Then it will be possible to determine the total volume of agricultural production (in value terms) and then to calculate the share of each type of product in the total volume.

Such a calculation, in order to conduct a factor analysis in the future, is carried out according to the data of the base year (initial or planned data) and the reporting year (final or actual data).

To calculate the equivalent production of each type of manufactured products in physical terms is carried out in the following sequence:

1. The cost (in comparable prices) of the total output in the reporting year (or the actual output of production) is alternately multiplied by the share of each type of product in the base year (planned share) and this determines the notional value (with the actual share and planned composition) of each type of product.

2. The notional value of each particular type of product is divided by the corresponding comparable price and thus the notional volume (in physical terms - centners, tons, etc.) of each type of crop and livestock production is calculated.

The proposed methodology will make it possible to carry out objective calculations of all the necessary values for factor models and to obtain a real estimate of the influence of factor indicators on the resultant, not only in the model of forming the total cost, but also in other factor models that simulate the processes of production and sales of products.

\section{REFERENCES}

[1] M.I. Bakanov, M.V. Melnik, A.D. Sheremet Theory of Economic Analysis. Moscow, Finance and Statistics (2005)

[2] V.R. Bank, S.V. Bank, A.V. Taraskin Financial analysis. Moscow, Prospect (2012)

[3] L.T. Gilyarovskaya, D.V. Lysenko, D.A. Endovitskiy Comprehensive economic analysis of economic activity. Moscow, Prospect (2006)
[4] V.V. Kovalev Financial analysis: methods and procedures. Moscow, Prospect (2002)

[5] G.V. Savitskaya Analysis of economic activity of the enterprise. Moscow, INFRA-M (2017)

[6] K. Hedderwick Financial and economic analysis of enterprises. Transl. from English. Ed. by Yu.N. Voropaev. Moscow, Finance and statistics (1996)

[7] E. Helfert Technique of financial analysis: The path to creating business value. Transl. from English. SaintPetersburg, Peter Book (2003)

[8] A.D. Sheremet, E.V. Negashev Methods of financial analysis of activities at commercial organizations. Moscow, INFRA-M (2016)

[9] N.V. Byshov, S.N. Borychev, D.E. Kashirin, G.D. Kokorev, M.Y. Kostenko, G.K. Rembalovich, A.A. Simdyankin, I.A. Uspenskiy, A.I. Ryadnov, R.A. Kosul'nikov, I.A. Yukhin, and I.K. Danilov Theoretical studies of the damage process of easily damaged products in transport vehicle body during the on-farm transportation. ARPN J. of Engin. and Appl. Sc., 13 (10), pp. 3502-3508 (2018)

[10] N.V. Byshov, S.N. Borychev, I.A. Uspenskiy, A.V. Shemyakin, I.A.Yukhin, D.A. Fedyashov, I.A. Piskachev Development Prospects of Transportation in the Agroindustrial Complex by Reducing the Damage of Fruit and Vegetable Products When using the Pneumatic Container. Intern. J. of Engin. and Tech., vol. 7, no. 4.36, pp. 914-919 (2018)

[11] N.V. Byshov, A.N. Bachurin, I.Yu. Bogdanchikov, D.O. Oleynik, Yu.V. Yakunin, A.V. Nelidkin Method and Device for Reducing the Toxicity of Diesel Engine Exhaust Gases. Intern. J. of Engin. and Tech., vol. 7, no. 4.36, pp. 920-928 (2018)

[12] A.S. Zavgorodnyaya, I.G. Shashkov., V.S. Konkina, L.V. Romanova, E.I. Mashkova, M.Yu. Pikushina Adaptive Management of the Agricultural Enterprise in the Conditions of Environmental Uncertainty. $J$. of Advanced Research in Dynam. and Contr. Systems, no. 7 (Special Issue), pp. 2022-2031 (2018)

[13] N.V. Byshov, S.N. Borychev G.N. Bakulina, V.V. Fedoskin, I.V. Fedoskina, M.Yu. Pikushina Systems analysis when evaluating and forecasting of agricultural enterprises. Religación. revista de ciencias sociales y humanidades, vol. 4, no. 18, pp. 390-404 (2019)

[14] V. Konkina Investment management in the dairy industry. BIO Web of Conferences, vol. 17 -00086 (2020)

[15] I.G. Shashkova, L.V. Romanova, S.V. Kornilov, P.S. Vershnev, E.I. Mashkova Staffing of agricultural organizations of Ryazan region in conditions of economy digitalization. BIO Web of Conferences, vol. 17 -00087. (2020)

[16] V. Konkina, A. Shemyakin, I. Babkin Information and software of managing the industry cluster of the region. Proceedings of the 33rd International Business Information Management Association Conference, IBIMA 2019: Education Excellence and Innovation Management through Vision 2020. pp. 8632-8637 (2019) 
[17]E.P. Polikarpova, I.E. Mizikovskiy Preparing accounting information on costs for manufactured crop production. Custos e Agronegocio, no. 14(4), pp. 149-166 (2018)

[18] S.D. Polischuk, G.I. Churilov, S.N. Borychev, N.V Byshov, A.A. Nazarova Nanopowders of cuprum, cobalt and their oxides used in the intensive technology for growing cucumbers. Intern. J. of Nanotechnology, vol. 15, no. 4-5, pp. 352-369 (2018)

[19]R.N. Ushakov, A.V. Ruchkina, V.I. Levin, O.A. Zakharova, N.A. Golovina Sustainability of Agro-Gray Soil to Pollution and Acidification, and its Biodiagnostics. Intern. J. of Engin. and Tech., vol. 7, no. 4.36, pp. 929934 (2018)

[20]I.Davydova, Y. Mazhayskiy, E. Davydov E. Petroleumcontaminated soils price regulation for the aids of land use optimization and ecological risk mitigation. Engineering for Rural Development, January, pp. 91-94. (2016)

\section{Creative Commons Attribution License $\mathbf{4 . 0}$ (Attribution 4.0 International, CC BY 4.0)}

This article is published under the terms of the Creative Commons Attribution License 4.0

https://creativecommons.org/licenses/by/4.0/deed.en_US 